\title{
Different levels of loyalty towards the higher education service: evidence from a small university in Spain
}

\section{Martina G. Gallarza and \\ Teresa Fayos-Gardó*}

Marketing Department,

Universidad de Valencia,

Avenida Taronjers s/n., Valencian Community, Valencia, Spain

Email: martina.gallarza@uv.es

Email: teresa.fayos@uv.es

*Corresponding author

\section{Francisco Arteaga-Moreno}

Biostatistics and Research Department, School of Medicine and Dentistry,

Universidad Católica de Valencia San Vicente Mártir,

C/ Quevedo, 2 46001, Valencia, Spain

Email: francisco.arteaga@ucv.es

\section{David Servera-Francés and Elena Floristán-Imizcoz}

Catholic University of Valencia,

Economy, Management and Marketing Department,

C/ Corona, 34, 46003 Valencia, Spain

Email: david.servera@ucv.es

Email: elena.floristan@ucv.es

\begin{abstract}
Higher Education Institutions (HEIs) operate in a competitive environment in which the universities must address issues of customer satisfaction and loyalty. This process requires that educational institutions carefully analyse the key factors contributing to student loyalty in all its dimensions and develop strategies accordingly. Customer loyalty is a consistent commitment deeply held by customers to re-purchasing and/or recommending the product or service. This paper aims at understanding the different levels of student loyalty towards HEIs through an empirical study run with 705 graduate students from a small University. According to the students' personal and situational characteristics (age and choice of degree course), we expect significant differences in the level of loyalty. We may also draw conclusions about the management of HEIs in terms of positive word of mouth among students.
\end{abstract}

Keywords: higher education service; consumer behaviour; loyalty; universities. 
Reference to this paper should be made as follows: Gallarza, M.G., FayosGardó, T., Arteaga-Moreno, F., Servera-Francés, D. and Floristán-Imizcoz, E. (2020) 'Different levels of loyalty towards the higher education service: evidence from a small university in Spain', Int. J. Management in Education, Vol. 14, No. 1, pp.36-48.

Biographical notes: Martina G. Gallarza $(\mathrm{PhD})$ is an Associate Professor in the Marketing Department of the Universidad de Valencia (SPAIN). She formerly taught at the Universidad Católica de Valencia, where she was Dean of the Business Faculty. Her research interests include consumer behaviour, non-profit marketing, and services marketing. Her particular research areas focus on perceived value related to satisfaction and loyalty. She has published articles in Annals of Tourism Research, Tourism Management, Journal of Consumer Behaviour, Journal of Services Marketing, International Journal of Hospitality Management, International Journal of Culture, Tourism and Hospitality Research, and International Journal of Voluntary and Non-profit Organisations, among others.

Teresa Fayos-Gardó $(\mathrm{PhD})$ is an Associate Professor in the Marketing Department of the Universidad de Valéncia (SPAIN). She formerly taught at the Universidad Católica de Valencia, where she was Vicedean of the Business Faculty. Her research interests include internationalisation, non-profit marketing, and retailing. She has published articles in International Business Review, The International Review of Retail, Distribution and Consumer Research, Journal of Consumer Behaviour, and International Journal of Voluntary and Non-profit Organisations, among others.

Francisco Arteaga-Moreno is a Vice-Rector of Research Development and Innovation at Catholic University of Valencia San Vicente Mártir (Spain). He holds the MSc in Mathematics and the PhD in Statistics. His research focuses on statistical techniques for quality and productivity improvement, especially those related to multivariate statistical projection methods, missing data, computer statistics, and biostatistics. He has papers published in several journals such as: Journal of Chemometrics, Chemometrics and Intelligent laboratory systems, Journal of Service Management, Journal of Hospitality Marketing and Management, International Journal of Hospitality Management, Voluntas: International Journal of Voluntary and Non-profit Organisations, Total Quality Management and Business Excellence, Annals of Tourism Research, Applied Stochastic Models in Business and Industry, Industrial Management and Data Systems, among others.

David Servera-Francés received $\mathrm{PhD}$ degree in Marketing. He is a Vice-Dean of Business Management and Assistant Professor in Marketing at the Catholic University of Valencia (Spain). His research interests are consumer behaviour, corporate social responsibility, logistics and retailing. He has published in international journals such as Industrial Marketing Management, International Review of Retail Distribution and Consumer Research, or Industrial Management and Data Systems Journal, Journal of Service Marketing, Journal of Product and Brand Management, among others.

Elena Floristán-Imizcoz $(\mathrm{PhD})$ is an Assistant Professor in Marketing at the Universidad Católica San Vicente Mártir (SPAIN). She formerly taught at the Universidad Católica de Valencia, where actually she is Vice-Rector of Strategic Coordination. Her research interests include basically consumer behaviour and non-profit marketing. Her particular research areas focus on volunteer and consumer perception. She has published articles in International Journal of Culture, Tourism and Hospitality Research, Esic Market, Economics and Business Journal and International Journal of Voluntary and Non-profit Organisations, among others. 
This paper is an updated and expanded version of a paper, entitled 'Different levels of loyalty as a consumer behaviour in Higher Education service: an approach in private universities' presented at the 'INTED-IATED', Spain, 2013.

\section{Introduction}

Higher Education Institutions (HEIs) operate in a competitive environment where, to be successful, it is vital that universities, like any other business, address issues of market orientation and customer satisfaction. Indeed, as recently stated "The Higher Education (HE) sector continues to face 'marketisation' challenges" (Kolar et al., 2018, p.1). These challenges are related to digitalisation, globalisation and a more customer-drive orientation (Brooks et al., 2017). Customer satisfaction and loyalty have explicitly been addressed in the last decade as key drivers for HEI performance (Agrawal and Tan, 2014; Annamdevula and Bellamkonda, 2016; Helgesen and Nesset, 2007; Ledden et al., 2007).

In consumer behaviour literature, loyalty is presented as a rich and multifaceted measure, with cognitive, affective and conative dimensions (Dick and Basu, 1994; Oliver, 1980, 1997, 2014). This paper aims at understanding the different levels of student loyalty in HEIs. It takes a two-pronged approach, both from a theoretical and empirical perspective. In the theoretical part, it presents the conceptual framework on loyalty and HE service. The empirical study is a quantitative analysis conducted in a small private Christian-oriented University, in Valencia (Spain), on graduate students' likelihood of choosing the same University and/or same degree course.

The idiosyncrasy of the HE service is that the consumer may consume just once. Therefore, the affective dimension of loyalty, i.e. the recommendation or the positive word of mouth (hereinafter WOM), is crucial for assessing the value offered to consumers (e.g., students, families and society). Market appeal in a more competitive environment for HEIs relates to positive WOM communication, as key strategic variable in maintaining a competitive position with long-term benefits arising from students' loyalty (Annamdevula and Bellamkonda, 2016; Arambewela, 2005; Fielder et al., 1993). This process requires HEIs to analyse the key factors contributing to student loyalty, in all its dimensions, and develop strategies accordingly.

Personal characteristics may moderate loyalty behaviour (Oliver, 2014). This paper aims at understanding the different levels of student loyalty in HEIs through an empirical study run with 705 graduate students from a private university in Spain with legal entity as a Foundation, and a Christian orientation. According to the students' personal and situational characteristics - age and choice of degree course (Business, Psychology, Nursing etc.) -, we expect significant differences in the level of loyalty.

\section{Conceptual framework}

\subsection{Loyalty and consumer behaviour}

Oliver (1999, p.34) defined customer loyalty as "a consistent commitment deeply held by customers to re-purchase the product or service in spite of situational impacts or promotional activities, which have the potential to cause switching behaviour". He identified various phases of customer loyalty (Dick and Basu, 1994) involving four 
different stages (Oliver, 1997): cognitive loyalty, affective loyalty, conative loyalty and action loyalty; therefore there are different ways to define perceived customer loyalty (Oliver, 2014). Cognitive loyalty is the initial phase, in which the brand attribute information available to the consumer indicates that one brand is preferable to its alternatives. In the second phase of loyalty development, the customer develops a liking or attitude toward the brand based on cumulatively satisfying uses. The third phase, conative loyalty, is the intention to re-purchase the brand. This stage is influenced by recurrent episodes of positive affection toward the brand. Finally, action loyalty studies the mechanism by which intentions are converted to actions (Oliver, 1999; Shen and Sengupta, 2018). These actions may be re-purchasing and/or positive recommendation.

Previous studies suggested that customer satisfaction in services may have different antecedents: service quality and perceived value are the most common (Cronin et al., 2000; Gallarza et al., 2016) although the prominence of one or the other is not universally accepted (Gallarza et al., 2011). Furthermore, customer loyalty is the main consequence of satisfaction (Gallarza et al., 2011; Annamdevula and Bellamkonda, 2016). Customer loyalty is thus the end of a sequence of effects (a service quality-value-satisfactionloyalty chain) (Gallarza et al., 2016). Accordingly, as a consumption outcome, any form of loyal behaviour should interest of researchers and practitioners.

Loyal customers are more likely to recommend the service to other customers (Keiningham et al., 2018). Although personal characteristics and particular situations may moderate this behaviour (Dick and Basu, 1994; Oliver, 2014), WOM is closely linked to customer loyalty (Shen and Sengupta, 2018), especially in services where repetition is not possible (Gallarza et al., 2016); such as HEs.

As initially indicated by Grewal et al. (2003), WOM was the passing of information from person to person, literally, through oral communication. However, nowadays a variety of subcategories in WOM communication have emerged (i.e. via various media such as internet, telephone, etc.) due to the rapid development of modern technology (Keiningham et al., 2018). Recent research found traditional WOM being even more effective than electronic WOM (Shen and Sengupta, 2018). Furthermore, according to Grewal et al. (2003), individuals do not recommend the product or service for an incentive but tend to engage in personal referrals from communicators they trust, so they are less receptive to the marketing influence of competitors.

\subsection{The higher education service and consumption behaviour}

Choosing and experiencing HE services is complex and may be understood as a high involvement behaviour (Fayos et al., 2011). This is due to several factors such as the wide range of choices (Maringe, 2006; Belanger et al., 2002) even wider nowadays because of globalisation erasing frontiers in University selection (Brooks et al., 2017) or a highly relativistic context (Pinna et al., 2018) where comparisons are made before experiencing the service (Roszkowski and Spreat, 2010).

It is well-known that both rational and emotional aspects are key drivers of HE service choice (Angulo et al., 2010). The context of this consumption is high risk because the return on the investment made by the consumer comes in the very long term (Ledden et al., 2007).

Student behaviour in the HEIs market has been a main subject of interest for service researchers in the 90s (e.g., in chronological order Fielder et al., 1993; Webb and Jagun, 1997; Browne et al., 1998). Justification for this interest lies not just in the importance of 
understanding choice behaviour, but also on student retention, as a form of loyalty behaviour (Annamdevula and Bellamkonda, 2016; Fielder et al., 1993; Harrison-Walker 2010).

With the fast-growing number of students in HE, it has become attractive for marketers to manage Universities as brands, offering customers a lifetime value. Universities can get students to engage with their brands, in search of a lifetime loyal customer. But, in comparison with other good/service offerings, HE service is a "credence good" (Lovelock and Wirtz, 2011; Zeithaml et al., 2013): it is difficult for customers to evaluate, even after purchase. Accordingly, customers rely heavily on information shared by other customers, and so HE marketers are particularly interested in obtaining likelihood to recommend and positive WOM.

\subsection{Strategic approach to customer loyalty in higher education}

Many nations have adjusted their financial system for HEIs in the past few years (OECD, 2004). It has helped HEIs to emphasise the educational profession and thus gradually become more performance-based (Arnaboldi and Azzone 2005; DeShields et al., 2005). Furthermore, as financing is partly dependent on students' academic and professional achievements, student loyalty has become an important driver when considering marketing strategies for HEIs (Agrawal and Tan, 2014). The optimal allocation of resources, which offers better values for students, will in turn guarantee financial funding in the future (Helgesen and Nesset, 2007).

Furthermore, forced by an increasingly competitive market, HEIs need to incorporate better market orientation, seeking to obtain competitive advantages over their competitors (Fielder et al., 1993). Thus, it is essential to analyse and study student satisfaction and loyalty in HE, because HEIs can greatly benefit from establishing long term relationships with students.

The outcomes drawn from the strengths and weaknesses of universities' offerings come from their stakeholders' overall perception (institution managers, teachers, employees, research investors and students, etc.). Regarding students, these outcomes are formed mainly by external WOM based on previous experiences, and HEIs' internal efforts such as marketing activities (Ivy, 2001).

Previous research shows that student satisfaction has a direct influence on loyalty (Webb and Jagun, 1997; Eskildsen et al., 1999). That is, students who are satisfied with their educational experience will demonstrate loyalty to that institution. As a consequence, they will involve themselves in positive WOM actions (Alves and Raposo, 2007).

The literature presents several ways of measuring student behavioural loyalty as retention. An institution's attrition or dropout rate is the rate at which students leave before graduating (Belanger et al., 2002). The opposite is the retention rate, as an indicator of how first-time students leave University after the intended number of years. Institutional retention is, therefore, the indicator of performance in a HE organisation. A higher retention rate shows student satisfaction in terms of issues such as the correlation between their expectations and actual experience. Nevertheless, loyalty can also be measured as the amount of student growth (Levitz et al., 1999), because it reflects the effectiveness of a campus on delivering what valued and respected students expect, need and want.

There are, however, dissatisfied students as well. Student dissatisfaction may have threatening consequences for the university, in the form of withdrawal or transfer of 
unsuccessful students (Alves and Raposo, 2007), as well as negative WOM harming future applications (Alves and Raposo, 2007; Belanger et al., 2002). Additionally, student loyalty is not a short-term consequence. As Helgesen and Nesset (2007) point out, throughout the educational process, students may reduce the number of chosen courses, switch from one educational institution to another or completely drop out. Furthermore, the college dropout rate may have considerable effects on institutional finance incurring a significant loss of revenue over the life of student cohorts (Belanger et al., 2002).

To sum up, loyal students may be good advocates for HEIs and they may also enhance the learning experience by active participation and other committed behaviour which ultimately improves teaching quality. Customer (students) loyalty is positively linked therefore to other critical aspects of the firm (the HEI) (Helgesen and Nesset, 2007). Moreover, after reviewing customer loyalty-related processes, the role of customer satisfaction has proved to be the common ground for customers staying with companies which foster successful relationships and offer satisfactory value.

\section{Empirical study: methodology and research questions}

According to the conceptual framework, different levels of loyalty behaviour may be identified within the HE services in terms of behavioural and attitudinal consequences of a service evaluation (Helgesen and Nesset, 2007). Among the latter, as re-purchase behaviour is less likely in the HE service (Fayos et al., 2011), repeat behaviour can be assessed when the University is chosen again for another program (Master's or an additional degree).

In the present study, we aim at exploring differences between these levels of loyalty behaviour, according to two variables: gender and type of degree course. We seek to empirically test that loyalty is a relativistic behaviour, which depends on persons and contexts. Consequently, the following research questions are proposed:

- $R Q 1$ : The likelihood of students choosing the same University varies according to the gender.

- $R Q 2$ : The likelihood of students choosing the same University varies according to the degree chosen.

We answer these questions with a Chi-square test of homogeneity, meaning that we test if the distribution of responses is significantly different between genders and degrees.

The setting chosen for our empirical research is a small university in the city of Valencia (east coast of Spain). The university arose from the union of different colleges with tradition (over 50 years in some cases) and has experienced significant growth in number of students and degrees. In fact, today, it has more than 14,500 students on 28 Degree and 22 Master's degree courses, taught by more than 1200 teachers spread over four campuses and 14 locations.

The survey was sent by e-mail to all undergraduate students in their last year (universe of 3124 students); this was the universe chosen, as last-year students are able to assess both their satisfaction with the service provided (the HE service) and the likelihood of recommending the service provider (the University). After the first e-mail, less than 400 answers were obtained; thus, a second round was undertaken by phone call, with a stratification by degrees matching the structure of the University; they were 
kindly asked to answer the e-questionnaire they were sent. After second round, 800 questionnaires were received, among which just a total of 705 were valid $(23 \%$ of universe).

Sample profile is depicted in Table 1: the sample was biased to women $(75.3 \%)$, aged between 22 and 25 (55\%), a distribution corresponding with the distribution of the whole University population; different degrees are represented, with a predominance of those related to Pedagogy and Social Sciences, corresponding as well with the University structure. Respondents came primarily from High School (67.4\%) although some started a previous degree at another University (15.3\%).

Table 1 Sample profile

\begin{tabular}{|c|c|c|}
\hline Total graduates & 705 & 100,0 \\
\hline Gender & $N$ & $\%$ \\
\hline Men & 174 & 24.7 \\
\hline Women & 531 & 75.3 \\
\hline Age & $N$ & $\%$ \\
\hline $22-25$ & 388 & 55.0 \\
\hline $26-30$ & 179 & 25.4 \\
\hline $31-35$ & 59 & 8.4 \\
\hline $36-40$ & 25 & 3.5 \\
\hline $41-45$ & 26 & 3.7 \\
\hline $46-50$ & 12 & 1.7 \\
\hline $51-55$ & 11 & 1.6 \\
\hline $56-57$ & 5 & 0.7 \\
\hline Degree & $N$ & $\%$ \\
\hline Business administration and management & 18 & 2.6 \\
\hline Social and cultural anthropology & 4 & 0.6 \\
\hline Sciences of physical activity and sport & 51 & 7.2 \\
\hline Marine sciences & 9 & 1.3 \\
\hline Social education & 7 & 1.0 \\
\hline Nursing & 104 & 14.8 \\
\hline History and science of music & 4 & 0.6 \\
\hline Speech therapy & 20 & 2.8 \\
\hline Specialised teacher in hearing and language & 17 & 2.4 \\
\hline Specialised teacher in special education & 38 & 5.4 \\
\hline Specialised teacher in physical education & 48 & 6.8 \\
\hline Specialised teacher in early childhood & 171 & 24.3 \\
\hline Specialised teacher in musical education & 27 & 3.8 \\
\hline Specialised teacher in elementary education & 70 & 9.9 \\
\hline Specialised teacher in foreign language (English) & 37 & 5.2 \\
\hline Master's degree & 58 & 8.2 \\
\hline Psychology & 10 & 1.4 \\
\hline Psychopedagogy & 5 & 0.7 \\
\hline Sociology & 1 & 0.1 \\
\hline Occupational therapy & 6 & 0.9 \\
\hline
\end{tabular}


Table 1 Sample profile (continued)

\begin{tabular}{lcc}
\hline Total graduates & 705 & 100,0 \\
\hline Coming from & $N$ & $\%$ \\
\hline Professional training & 85 & 12.1 \\
Bachelor - high school & 475 & 67.4 \\
Over 25 years old (late access to University) & 19 & 2.7 \\
Previous degree at another University & 108 & 15.3 \\
Other studies (validated titles) & 16 & 2.3 \\
N.A. & 2 & 0.3 \\
\hline Total graduates & 705 & 100.0 \\
\hline
\end{tabular}

\section{Findings and results}

Among the 705 individuals in the sample, 681 (96\%) stated that if they were to decide now (repurchase intention), they would decide to go to College or University again (in general, not to a particular University). Only 19 said they would not attend College again, and 5 did not answer this question. The remaining 681 who indicated they would study for a degree again were asked if they would do so at the same university. 552 individuals (81.06\%) answered affirmatively. Only $14.83 \%$ said no, and 28 students $(4.11 \%)$ did not answer this question. A result of $80 \%$ loyalty (intention to repeat) is a rather high score, considering the specific features of consumers in this HE service (already described as high involvement, high risk and longer return on investment).

Table 2 shows the number and percentage of responses and the gender distribution. This distribution is shown in Figure 1 in graph form.

Figure 1 Likelihood of choosing the same university, \% distribution by gender

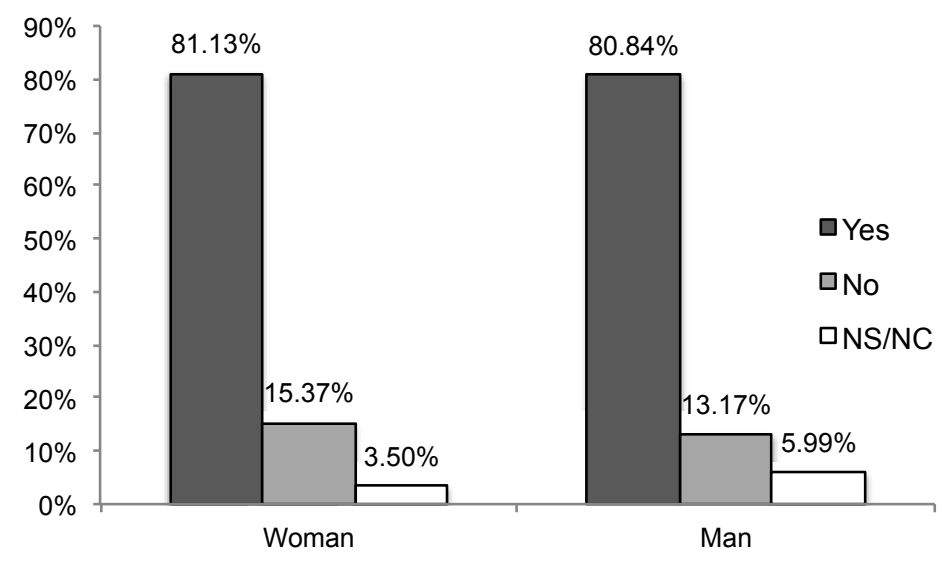

Our interest is finding out whether the distribution of loyalty (likelihood of choosing the same University) is the same between genders. Table 2 is the basis for an independencehomogeneity Gi-2 test aiming at refuting that loyalty (likelihood of choosing the same 
University) is equally distributed between genders. The X2 statistic is 2.31 ( $p$-value with 2 degrees of freedom $=0.316$ ).

Table 2 Likelihood of choosing the same university, by gender (number and distribution)

\begin{tabular}{lccccccc}
\hline & \multicolumn{2}{c}{ Yes } & No & \multicolumn{3}{c}{ NA } & Total \\
\hline Women & 417 & $(81.13 \%)$ & 79 & $(15.37 \%)$ & 18 & $(3.50 \%)$ & 514 \\
\hline Men & 135 & $(80.84 \%)$ & 22 & $(13.17 \%)$ & 10 & $(5.99 \%)$ & 167 \\
Total & 552 & & 101 & & 28 & & 681 \\
\hline
\end{tabular}

Our conclusion is that there is insufficient evidence to reject the assumption of equal distribution and, therefore, we accept that loyalty is equally distributed between genders, meaning that women and men are equally likely to choose the same University, provided that they are in the same situation. This result is interesting in light of the sociological shift that Spanish Universities have been witnessing in recent years, where a much higher proportion of women is accessing degrees that are becoming highly "feminine" (Medicine, Teaching, Nursing,...). Although men and women may make different choices, these differences do not persist in their loyalty behaviour at the end of the studies.

It is also interesting to study the level of loyalty (likelihood of choosing the same University) by degree course. This can be seen in Table 3 and, in Figure 2 in graph form (this figure only shows degrees with 10 or more responses).

Table 3 Likelihood of choosing the same university, by degree

\begin{tabular}{lcccccc}
\hline Degree & \multicolumn{2}{l}{ Yes } & \multicolumn{2}{l}{$N o$} & \multicolumn{2}{l}{$N A$} \\
\hline ST* in Early Childhood (167) & 146 & $(87.4 \%)$ & 19 & $(11.4 \%)$ & 2 & $(1.2 \%)$ \\
Nursing (101) & 83 & $(82.2 \%)$ & 14 & $(13.9 \%)$ & 4 & $(4.0 \%)$ \\
\hline ST in Elementary Education (68) & 58 & $(85.3 \%)$ & 9 & $(13.2 \%)$ & 1 & $(1.5 \%)$ \\
Master's degree (55) & 46 & $(83.6 \%)$ & 7 & $(12.7 \%)$ & 2 & $(3.6 \%)$ \\
\hline Sciences of Physical Activity and Sport (47) & 30 & $(63.8 \%)$ & 12 & $(25.5 \%)$ & 5 & $(10.6 \%)$ \\
ST in Physical Education (47) & 37 & $(78.7 \%)$ & 6 & $(12.8 \%)$ & 4 & $(8.5 \%)$ \\
\hline ST in Foreign Language (37) & 31 & $(83.8 \%)$ & 4 & $(10.8 \%)$ & 2 & $(5.4 \%)$ \\
ST in Special Education (36) & 33 & $(91.7 \%)$ & 2 & $(5.6 \%)$ & 1 & $(2.8 \%)$ \\
\hline ST in Musical Education (26) & 23 & $(88.5 \%)$ & 1 & $(3.8 \%)$ & 2 & $(7.7 \%)$ \\
Speech Therapy (20) & 15 & $(75.0 \%)$ & 3 & $(15.0 \%)$ & 2 & $(10.0 \%)$ \\
\hline Business Administration and Management (17) & 10 & $(58.8 \%)$ & 5 & $(29.4 \%)$ & 2 & $(11.8 \%)$ \\
ST in Hearing and Language (17) & 12 & $(70.6 \%)$ & 5 & $(29.4 \%)$ & 0 & $(0.0 \%)$ \\
\hline Psychology (10) & 9 & $(90.0 \%)$ & 1 & $(10.0 \%)$ & 0 & $(0.0 \%)$ \\
Marine Sciences (7) & 2 & $(28.6 \%)$ & 4 & $(57.1 \%)$ & 1 & $(14.3 \%)$ \\
\hline Social Education (7) & 3 & $(42.9 \%)$ & 4 & $(57.1 \%)$ & 0 & $(0.0 \%)$ \\
Psychopedagogy (5) & 5 & $(100 \%)$ & 0 & $(0.0 \%)$ & 0 & $(0.0 \%)$ \\
\hline Occupational Therapy (5) & 2 & $(40.0 \%)$ & 3 & $(60.0 \%)$ & 0 & $(0.0 \%)$ \\
\hline Social and Cultural Anthropology (4) & 3 & $(75.0 \%)$ & 1 & $(25.0 \%)$ & 0 & $(0.0 \%)$ \\
\hline History and Science of Music (4) & 3 & $(75.0 \%)$ & 1 & $(25.0 \%)$ & 0 & $(0.0 \%)$ \\
\hline Sociology (1) & 1 & $(100 \%)$ & 0 & $(0.0 \%)$ & 0 & $(0.0 \%)$ \\
\hline
\end{tabular}

Note: $\quad *$ The abbreviation ST means specialised teacher 
Figure 2 Likelihood of choosing the same university, distribution by degree

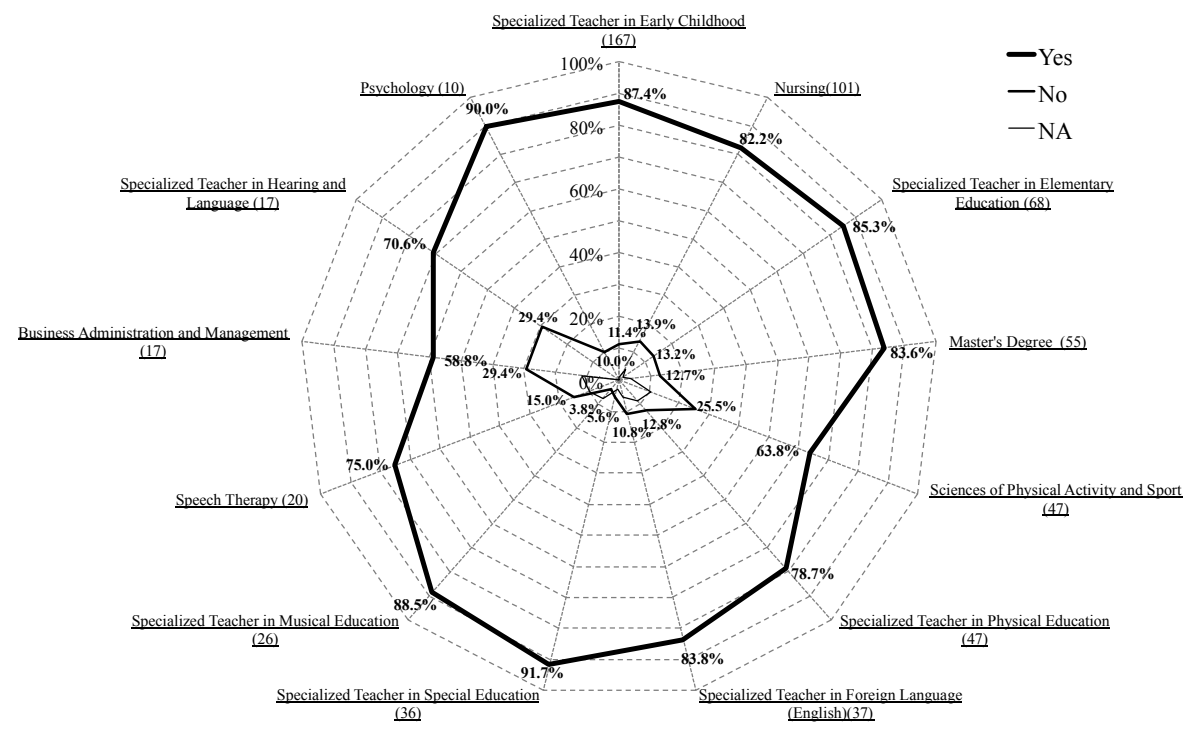

Figure 2 shows in bold, the percentage of students that would choose the same institution. The two thin lines show respectively negative answers, and no responses: loyalty levels are all rather high, shown by the differences between the bold line and the two thin lines.

According to the respondents' degree in the sample, the highest levels of loyalty toward the institution are found in Special Education (91.7\%) and Psychology (90\%). It is worth mentioning the $100 \%$ level of loyalty obtained for the degree courses in Sociology and Psychopedagogy; but, due to the small size of the subsample, this result must be considered with caution (and thus it is not depicted in Figure 2, but it is shown in Table 3).

As mentioned, regarding the distribution by degree courses, it is not possible to confirm whether or not significant differences exist because the range of sub-sample sizes is too diverse. The lack of statistical information is acknowledged as a primary limitation of this research; nevertheless, the descriptive results do show differences across degree courses, which can be read in the light of different levels of commitment shown by students on one degree course or another.

Another way of reading the differences between levels of loyalty by degree courses may correspond to the nature of the degree: more vocational courses have an intrinsic motivation that enhances the likelihood of choosing the same degree; whereas students showing more utilitarian decisions in their choices might be less keen to attend the same degree course again (and may show likelihood to changing to another complementary area).

Table 3 presents a very high level of behavioural loyalty shown by Postgraduate or Master Students (83.6\%). Postgraduate students are presumed to be more mature and wiser in their choice than undergraduate students. Sample size does not allow further insights, but intrapersonal comparisons between students that have studied for a Degree and a Master's degree at the same institution may shed better light on this distinction, and is thus proposed for further research. 


\section{Conclusions}

This paper examines student behaviour in the HEIs market, which has been a main concern for a long time among service researchers during the 1990s and 2000s. In comparison to previous works dealing more with satisfaction and perceived value (e.g., Alves and Raposo 2007; Ledden et al., 2007), this paper focuses specifically on loyalty behaviour as a final outcome, as a consequence of both value and satisfaction (Gallarza, et al., 2016)., with a twofold nature: behavioural as the intention to re-purchase, and attitudinal as the intention to recommend. The findings are based on a survey conducted among 705 students from a small University in the city of Valencia (SPAIN). Differences between men and women in their level of loyalty, assessed as the likelihood of choosing the same University (same situation, same choice) were found to be not significant. This is a plausible result given the non-existence of gender differences in the choice and access to University. However, differences found among the degree courses show how some degrees (Humanities) reveal more vocational decisions than the more utilitarian ones (Business), with higher levels of loyalty as a WOM action for the former that for the latter.

Several limitations of this study must be acknowledged. First, we haven't addressed relationships effect (such as correlations or causality) between levels of satisfaction and levels of loyalty, despite the broad consensus in the literature (e.g., Ledden et al., 2007; Cronin et al., 2000; Gallarza et al., 2016). Second, a single HEI has been examined (convenience sample), with its peculiarities (small size, skewed to a feminine profile, and predominance of Humanities degrees). Third, no differences have been found between students that come directly from high school, and those who started a previous degree at another University. This information should be very interesting for HEIs' managers, in the sense that these students have more insights to make a comparison with, In fact, the very high levels of intention to repeat found in this study show that this second choice is in general terms, a wise one. Fourth, no information was provided on the effects of other demographics (e.g., age, habitat, social class). In that sense, re-purchase intention could also be viewed as a valuable instrument for segmenting students and thus positioning Universities, offering improved understanding for services consumer research and strategic management of HEIs.

Further applications of the proposals contained in this paper should reinforce the idea that research on all aspects of loyalty behaviour can broaden our vision and understanding of the HE service as a multifaceted consumption experience. In this sense, as recent proposals show (e.g., Kolar et al., 2018), other stakeholders such as employees (teachers and others) could be inquired, to measure correlations between internal quality, level of satisfaction towards the University, and intention to recommend. This would broaden the scope of what loyalty means for a HEI in terms of drivers and stakeholders. Furthermore, the connection between the digital dimension of the students' behaviour during their decision process (Pinna et al., 2018) and the likelihood of recommending and/or re-purchasing appears as a possible further stream of research. As social networks can sometimes even induce consumers to alter their decisions after obtaining further information online, and their importance has become key for HEIs (Brooks et al., 2017), a potential reformulation of the present work could be assessing, in a longitudinal study, the effects of electronic communications from students via social media and the effects on loyalty behaviour in the HE market. All these streams strengthen the interest of 
developing further knowledge on the peculiarities of choosing and recommending HEIs, as a cognitive-affective behaviour, This would offer further relevant information for managing Universities in a global world.

\section{References}

Agrawal, A. and Tan, V.M. (2014) 'Exploring determinants of students' experience, perceptions and loyalty intentions in higher education institutions', International Journal of Management in Education, Vol. 8, No. 4, pp.343-361.

Alves, H. and Raposo, M. (2007) 'Conceptual model of student satisfaction in higher education', Total Quality Management and Business Excellence, Vol. 18, No. 5, pp.571-588.

Angulo, F., Pergelova, A. and Rialp, J. (2010) 'A market segmentation approach for higher education based on rational and emotional factors', Journal of Marketing for Higher Education, Vol. 20, No. 1, pp.1-17.

Annamdevula, S. and Bellamkonda, R.S. (2016) 'The effects of service quality on student loyalty: the mediating role of student satisfaction', Journal of Modelling in Management, Vol. 11, No. 2, pp.446-462.

Arambewela, R. (2005) 'Postgraduate international students from Asia: factors influencing satisfaction', Journal of Marketing for Higher Education, Vol. 15, No. 2, pp.105-127.

Arnaboldi, M. and Azzone, G. (2005) 'Incrementalism and strategic change: a university's experience', International Journal of Educational Management, Vol. 19, No. 7, pp.552-563.

Belanger, C., Mount, J. and Wilson, M. (2002) 'Institutional image and retention', tertiary education and management, Vol. 8, No. 3, pp.217-230.

Brooks, J.S., Normore, A.H. and Wilkinson, J. (2017) “"Guest editorial”, International Journal of Educational Management, Vol. 31, No. 5, pp.562-563.

Browne, B.A., Kaldenberg, D.O., Browne, W.G. and Brown, D.J. (1998) 'Student as customer: factors affecting satisfaction and assessments of institutional quality', Journal of Marketing for Higher Education, Vol. 8, No. 3, pp.1-14.

Cronin, J.J., Brady, M.K. and Hult, G.T.M. (2000) 'Assessing the effects of quality, value and customer satisfaction on consumer behavioural intentions in service environments', Journal of Retailing, Vol. 76, No. 2, pp.193-218.

DeShields, Jr., O.W., Kara, A. and Kaynak, E. (2005) 'Determinants of business student satisfaction and retention in higher education: applying Herzberg's two-factor theory', International Journal of Educational Management, Vol. 19, No. 2, pp.128-139.

Dick, A.S. and Basu, K. (1994) 'Customer loyalty: toward an integrated conceptual framework', Journal of the Academy of Marketing Science, Vol. 22, No. 2, pp.99-113.

Eskildsen, J.K., Martensen, A., Gronholdt, L. and Kristensen, K. (1999) 'Benchmarking students' satisfaction in higher education based in the ECSI methodology', Proceedings of the Conference from TQM for Higher Education Institutions, Higher Education Institutions and the Issue of Total Quality, pp.385-402.

Fayos, T., Gallarza, M.G., Servera, D. and Arteaga, F. (2011) 'Análisis y evaluación del servicio de formación universitaria: implicaciones para el marketing estratégico de las universidades', Revista de Investigación en Educación, Vol. 9, No. 2, pp.133-152.

Fielder, J.S., Hilton, C.B. and Motes, W.H. (1993) 'Educational services marketing: a proposed system for enhanced recruitment of students', Journal of Professional Services Marketing, Vol. 8, No. 1, pp.191-205.

Gallarza, M.G., Arteaga-Moreno, F., Del Chiappa, G. and Gil-Saura, I. (2016) 'Intrinsic value dimensions and the value-satisfaction-loyalty chain: a causal model for services', Journal of Services Marketing, Vol. 30, No. 2, pp.165-185. 
Gallarza, M.G., Gil-Saura, I. and Holbrook, M.B. (2011) 'The value of value: further excursions on the meaning and role of customer value', Journal of Consumer Behaviour, Vol. 10, No. 4, pp.179-191.

Grewal, D., Iyer, G.R., Krishnan, R. and Sharma, A. (2003) 'The internet and the price-valueloyalty chain', Journal of Business Research, Vol. 56, No. 1, pp.391-398.

Harrison-Walker, L.J. (2010) "Customer prioritisation in higher education: targeting "right" students for long-term profitability', Journal of Marketing for Higher Education, Vol. 20, No. 2, pp.191-208.

Helgesen, Q. and Nesset, E. (2007) 'What accounts for students' loyalty? Some field study evidence', International Journal of Educational Management, Vol. 21, No. 2, pp.126-143.

Ivy, J. (2001) 'Higher education institution image: a correspondence analysis approach', International Journal of Educational Management, Vol. 15, No. 6, pp.276-282.

Keiningham, T.L.; Rust, R.T. Lariviere, B., Aksoy, L. and Williams, L. (2018) A roadmap for driving customer word-of-mouth', Journal of Service Management, Vol. 29, No. 1, pp.2-38.

Kolar, T., Erčulj, V. and Weis, L. (2018) 'Multi-group validation of the service quality, customer satisfaction and performance links in higher education', The Services Industries Journal. Doi: 10.1080/02642069.2018.1460361

Ledden, L., Kalafatis, S.P. and Samouel, P. (2007) 'The relationship between personal values and perceived value of education', Journal of Business Research, Vol. 60, No. 1, pp.965-974.

Levitz, R.S., Noel, L. and Richter, B.J. (1999) 'Strategic moves for retention success', in Gaither, G.H. (ed.): New Directions for Higher Education, Promising Practices in Recruitment, Remediation, and Retention, Jossey - Bass, San Francisco, pp.31-50.

Lovelock, C. and Wirtz, J. (2011) Services Marketing: People, Technology, Strategy, 7th ed., Prentice Hall, New York.

Maringe, F. (2006) 'University and course choice: implications for positioning, recruitment and marketing', International Journal of Educational Management, Vol. 20, No. 6, pp.466-479.

OECD (2004) Organisation for Economic Co-operation and Development, Education at a Glance, Paris, OCDE.

Oliver, R.L. (1980) 'A cognitive model of the antecedents and consequences of satisfaction decisions', Journal of Marketing Research, Vol. 17, No. 1, pp.460-469.

Oliver, R.L. (2014) 'Loyalty: its biogenic, psychological, and social origins - answering the question of "why Y?", Handbook of service marketing research, pp.70-96.

Oliver, RL. (1997) Satisfaction: A behavioural perspective on the consumer, McGraw Hill, New York.

Oliver, RL. (1999) 'Whence consumer loyalty?', Journal of Marketing, Vol. 63, No. 2, pp.33-44.

Pinna, M., Del Chiappa, G. and Gallarza, M.G. (2018) 'Factors and information sources influencing students' consumer behaviour: a case study at an Italian public university', International Journal of Management in Education, Vol. 12, No. 4, pp.351-374.

Roszkowski, M.J. and Spreat, S. (2010) 'Weighing the difference: the validity of multiplicative and subtractive approaches to item weights in an instrument assessing college choice decisions', Journal of Marketing for Higher Education, Vol. 20, No. 2, pp.209-239.

Shen, H. and Sengupta, J. (2018) 'Word of mouth versus word of mouse: speaking about a brand connects you to it more than writing does', Journal of Consumer Research, Vol. 45, No. 3, pp.595-614.

Webb, D. and Jagun, A. (1997) 'Customer care, customer satisfaction, value, loyalty, and complaining behaviour: validation in a UK university setting', Journal of Consumer Satisfaction, Dissatisfaction and Complaining Behaviour, Vol. 10, No. 1, pp.139-151.

Zeithaml, V.A., Bitner, M.J. and Gremler, D.D. (2013) Services Marketing: Integrating Customer Focus across the Firm, McGraw - Hill International Edition, New York. USA. 